\title{
Full mouth rehabilitation with a few remaining teeth and implants for a patient with chronic periodontitis: a case report
}

\author{
Eun-Jung Shin', Mong-Sook Vang', Hong-So Yang ${ }^{1 *}$, Sang-Won Park,2, Hyun-Pil Lim¹, Kwi-Dug Yun ${ }^{1}$ \\ 'Department of Prosthodontics, School of Dentistry, Chonnam National University, Gwangju, Republic of Korea \\ ${ }^{2}$ RIS Foundation for Advanced Biomaterials, School of Dentistry, Chonnam National University, Gwangju, Republic of Korea
}

\begin{abstract}
Chronic periodontitis involves subsequent loss of teeth, and if left untreated, can lead to adjacent teeth drifting and supraeruption of the rest dentition. Careful consideration has to be given when deciding extraction of remaining teeth in treatment of periodontally compromised dentitions. For tooth-supported fixed partial dentures or removable partial dentures, periodontally compromised teeth are extracted due to possible early failure from functional overload, but for implant restoration, the teeth could be used as supports for fixed partial dentures because implants can reduce overload on teeth. The remaining natural teeth can help clinicians restoring vertical dimension and normal occlusal plane in full mouth rehabilitation because it conserves patients' proprioceptive response. This clinical report describes treatment of a patient who has a few remaining teeth and supraeruption of the rest dentition from severe chronic periodontitis. Satisfactory clinical result was achieved with full mouth rehabilitation using a few teeth and implants. (J Dent Rehabil Appl Sci 2015;31(3):253-61)
\end{abstract}

Key words: chronic periodontitis; a few remaining teeth; dental implants; mouth rehabilitation

\begin{abstract}
서론
심한 치주질환에 의한 치아상실을 장기간 방치할 경우 인접치열 및 대합치열의 이상까지 발생하게 된다. 이러 한 치주질환 환자 치료시 치주 건강을 회복할 수 있도록 원인을 고려한 광범위한 치료가 필요하다. 또한 기능과 심미를 회복하기 위해 전악 수복 보철치료가 필요할 수 도 있다. ${ }^{1,2}$ 심한 치주질환 환자 치료시 가능하면 자연치 를 유지하는 것이 바람직하나, 치주적인 예후와 보철 계 획에 따라 발치 치아를 결정해야 하는 경우가 있다. 발치 후 상실부위는 치주적으로 건강한 환자와 동일하게 임플 란트로 성공적인 치료가 가능하나 주기적인 치주관리가 수반되어야 한다. ${ }^{3,4}$
\end{abstract}

*Correspondence to: Hong-So Yang

Professor, Department of Prosthodontics, School of Dentistry, Chonnam National University, 33, Yongbong-ro, Buk-gu, Gwangju, 61186, Republic of Korea

Tel: +82-62-530-5638, Fax: +82-62-530-5639, E-mail: yhsdent@jnu.ac.kr

Received: June 15, 2015/Last Revision: July 21, 2015/Accepted: July 27, 2015
임상가들 사이에서 치주적으로 예후가 좋지 않은 치아 를 치주치료하는 것은 임플란트 치료에 비해 예후가 불 확실하고 시간소요가 많다고 여겨지고 있어 중등도나 심 한 치주질환 환자의 경우 치아 발치 후 임플란트를 이용 하여 수복하는 경우가 많다. 이것은 임플란트가 치주적 으로 예후가 좋지 않은 치아보다 기능을 더 잘하고 치주 질환 감수성에 관계없이 임플란트 수명이 길다는 믿음하 에 이뤄지고 있다. 일부에서는 자연치를 유지하는 것이 더 나은 치료가 될 수 있음에도 불구하고 임플란트 시술 에 너무 확신을 갖고 예후가 불확실한 비싼 치료를 하는 경우도 있다고 주장하는 임상가들도 있다. 이 임상가들 은 골부족이나 임플란트 주위염에 의한 임플란트의 실패 위험성에 주목한다. 골부족시 상악동 거상술과 같은 골

Copyright@ 2015 The Korean Academy of Stomatognathic Function and Occlusion. (c) It is identical to Creative Commons Non-Commercial License. 
증대술로 해결할 수도 있지만 시간과 비용이 많이 소요 되는 단점이 있다. 이러한 점을 고려할 때 치주염 환자 의 치료계획시 자연치 발치에 대해 더욱 신중을 기해야 할 것이다.

Ekelund 등 과 Attard와 Zarb ${ }^{6}$ 는 하악 전악 임플란트 고정성 보철물에 대한 20년간의 추적연구에서 년간 골 소실이 매우 적지만 다양한 범위로 나타난다고 발표했 다. 그러나 이 연구에서는 자연치 발치 원인에 대한 언 급이 없어 심한 치주염 환자에 있어서 임플란트 주위 골 소실 정도를 알 수 없었다. 몇몇 연구에서 단일 또는 다 수 임플란트에서 임플란트 주위염(적어도 $2 \mathrm{~mm}$ 의 방사 선학적 주위골소실)의 5 - 10년간 발생율이 $16-28 \%$ 을 보인다고 했고, 다수 임플란트에서 더 많이 발생하고, 치주적으로 건강한 환자보다 치주질환 이력이 있는 환 자가 더 취약하다고 했다. ${ }^{7-9}$ 치주염에 의한 치아 상실 환 자와 치주염과 무관한 치아 상실 환자에 있어서 임플란 트 성공율을 비교한 종설 논문에서 상부보철물과 임플 란트 각각의 생존율은 두 군에서 통계적으로 유의한 차 이가 없었지만, 임플란트 주위염에 있어서는 치주염으 로 발치한 환자 그룹에서 통계적으로 유의하게 높은 발 병율을 보였다. 그러나 결론적으로는 치주질환 감수성 이 높은 환자에 있어서 임플란트 치료가 비적응증이 아 니라고 했고, 이러한 환자 치료에 있어서 주의사항은 임플란트 식립 전 치주치료를 통하여 감염원을 제거해 야 하고, 주기적인 유지관리 프로그램이 필요하다고 했 다. ${ }^{10}$ 본 증례는 심한 치주질환 환자에서 치주적으로 예 후가 좋지 않은 치아를 발치하고 소수치를 잔존시켜 상 실부위는 임플란트로 전악 수복한 증례로 소수 잔존치 의 치료결과에 대한 장기간 예후를 알아보고자 한다.

\section{증례 보고}

본 증례는 62세 남자 환자로서 치아가 흔들려서 임플 란트 치료받고 싶다는 주소로 내원하였다. 초진 내원시 방사선 사진과 구강검사를 시행한 결과 만성 치주염으 로 다수 치아 상실, 인접치아의 경사와 대합치의 정출로 인해 교합평면이 붕괴된 상태였다(Fig. 1). 안모는 좌우 대칭이었고, temporomandibular joint (TMJ), 안면근육 모두 정상이었으나 치아 상실과 골소실로 인해 순치각 의 소실, 비주인중각의 증가, 구순폭의 감소 등 측모가 오목한 모습을 보였다(Fig. 2). 치료계획은 심한 동요도 로 인해 예후가 불량한 것으로 판단된 상악의 모든 잔존
치를 발치하고, 하악의 경우 동요도, 잔존골의 양, 악골 에서의 위치가 양호하여 지대치로 사용 가능하다고 판 단된 하악 좌측 제 1,2 소구치와 제1대구치, 우측 제1소 구치를 남기고 치주적으로 예후가 좋지 않은 치아를 발 치하고, 다수의 임플란트를 식립하여 고정성 보철물로 수복하기로 계획했다.

발치 후 하악 잔존치에 임플란트 식립 전 치주치료를 시행했다. 정출로 인해 교합평면 수정이 필요한 잔존치 에 근관치료를 시행하고, 적합한 수직고경을 평가하여 진단 왁스업을 시행했다. 임시의치 제작을 위해 알지네 이트(Cavex Impressional, Cavex Holland BV, Haarlem, Netherlands)로 상하악 인상채득했다. 작업 모형에 교 합제를 제작하여 구강내 장착 후 동공간선과 캠퍼 평면 (비익-이주선)에 일치되게 하고, 생리적인 안정위를 사 용하여 수직고경을 결정한 후, 적절한 안모형태가 되게

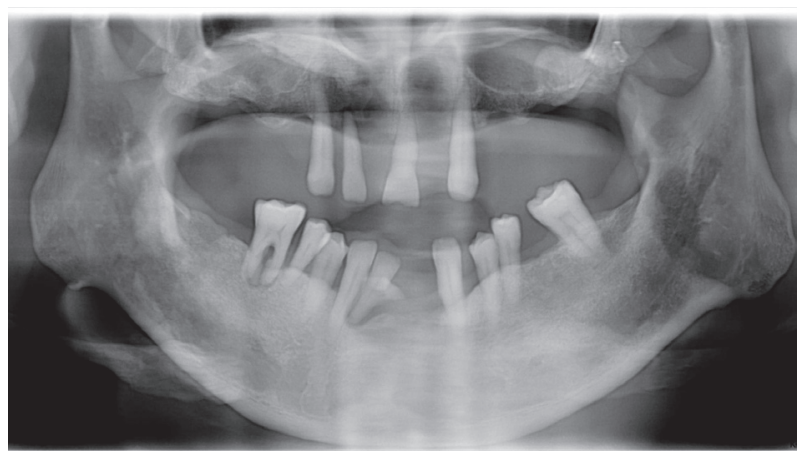

Fig. 1. Panogramic radiograph at first visit; Multiple teeth loss, shifting teeth, supraeruption of the rest dentition and severe periodontitis.
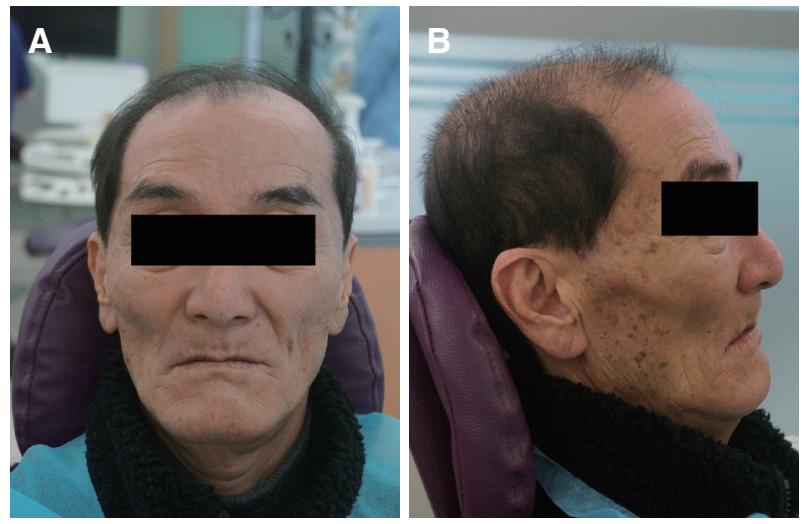

Fig. 2. Extraoral photos at first visit. (A) Frontal view, (B) Side view. 
교합제를 조정했다. 교합인기재(Regisil Rigid, Dentsply, Konstanz, Germany)로 중심위를 채득하여 임시의치 를 제작했다. 상하악 임플란트 식립을 위해 임시의치 를 복제하여 방사선스텐트(radiographic stent)를 제작 하여 전산화단층촬영 (computed tomography, CT; CB MercuRay, Hitachi, Tokyo, Japan)을 시행하였다. 촬영된 $\mathrm{CT}$ 영상을 분석하여 상, 하악 상실부위에 임플란트(US II, TS, Osstem, Busan, Korea)를 식립했다(Fig. 3).

임시치아 제작을 위해 임플란트 식립한 후 6 개월 이 지나서 개인트레이 제작을 위해 알지네이트(Cavex Impressional, Cavex Holland BV)로 상하악 인상채득 했다. 임플란트 코핑 연결 후 폴리비닐실록산 인상재 (Honigum ${ }^{\circledR}$ Mono, Light, DMG, Hamburg, Germany) 로 pickup 인상채득하여 주모형을 제작했다(Fig. 4). 고 딕아치(Centric guide system, Kuwotech, Gwangju,

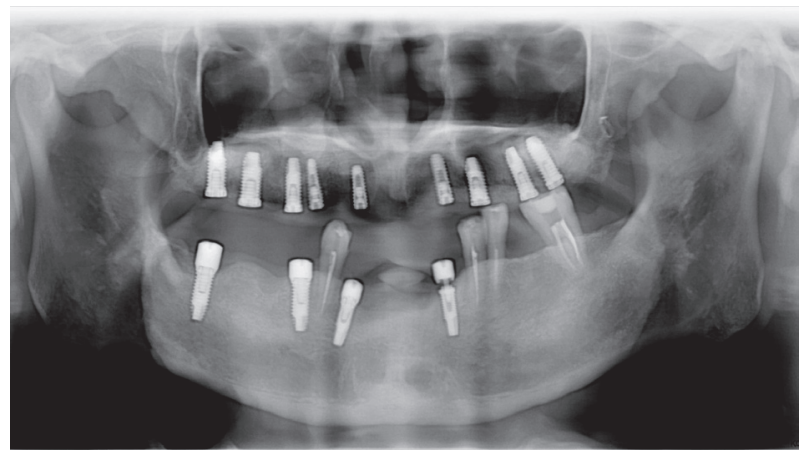

Fig. 3. Implant installation; Panoramic view. \#17i, 16i, 45i, 47i: US II Ф5.0 x 11 mm, \#14i, 24i: US II Ф4.0 x 10 mm, \#26i, 27i: US II Ф4.5 x 11 mm, \#33i, 43i: US II Ф3.5 x $11 \mathrm{~mm}, 13 \mathrm{i}, 11 \mathrm{i}, 23 \mathrm{i}$ : TS Ф3.5 x $11.5 \mathrm{~mm}$ (Osstem, Busan, Korea).

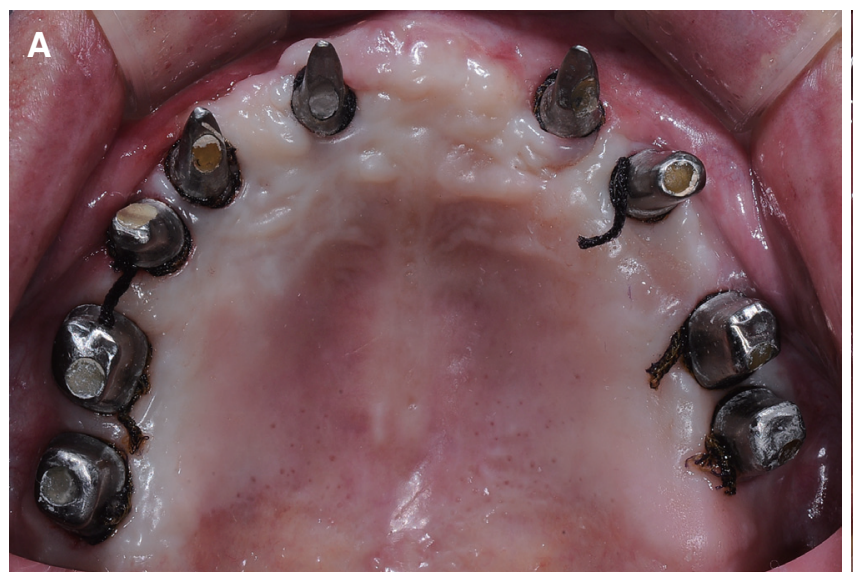

Korea)와 Willis method로 중심위, 수직고경을 결정하 고, 치아 정중선 정보를 기록한 후 안궁이전하여 반조절 성 교합기에 마운팅하여 CAD/CAM (Milling machine: 450i, imes-icore, Eiterfeld, Germany)으로 맞춤 지대주 와 임시치아(PMMA disk, Yamahachi, Gamagori, Japan) 제작했고, 교합은 견치 유도 교합을 부여했다(Fig. 5). 2 개월간의 임시 수복물 사용기간 동안 환자의 구순지지, 전치부 치축각도, 치아길이 수정하였고 적절한 전치 유 도, 견치 유도가 부여되도록 임시 수복물을 수정했다. 임시치아 장착 후 T scan (Tekscan, Inc., Boston, MA, USA)으로 균일한 중심위 교합을 확인했고, 견치 유도 교합이 됨을 확인했다. 환자분은 견치 유도 교합에 거부 감이 없었고 Willis method, 환자 발음 등으로 적절한 수 직고경이 됨을 확인했다. 환자분 동의하에 CT로 확인한 결과. 정상적 관절강을 보이고 과두가 관절와 내에 적절 한 위치에 있는 것을 확인했다. 임시치아 상태에서 두부 계측분석한 결과 임시 치아의 교합평면 전후방 기울기 가 정상범주 안에 들고, 하악이 시계방향 또는 반시계방 향으로 회전되지 않았음을 확인했다.

2개월간 임시치아 사용한 후 ARCUS digma II (ARCUS ${ }^{\circledR}$ digma II, Kavo Dental GmbH, Riss, Germany) 로 안궁이전을 시행했다. 교차 마운팅을 위한 바이트 를 채득하고(Fig. 6), 임시치아의 체크 바이트로 얻어 낸 과로각과 전방유도의 정보로 $\mathrm{KAVO}$ 교합기 $(\mathrm{KaVO}$ PROTAR Evo 7, Kavo Dental GmbH)에 마운팅했다 (Fig. 7, 8). 전방유도는 customized anterior guidance table를 만들었다. 지대주 레벨에서 인상채득하여 교 차 마운팅하여, $\mathrm{KAVO}$ 교합기에 기록된 과로각과 전

Fig. 4. Impression for provisional restoration. (A) Maxillary occlusal view, (B) Mandibular occlusal view. 


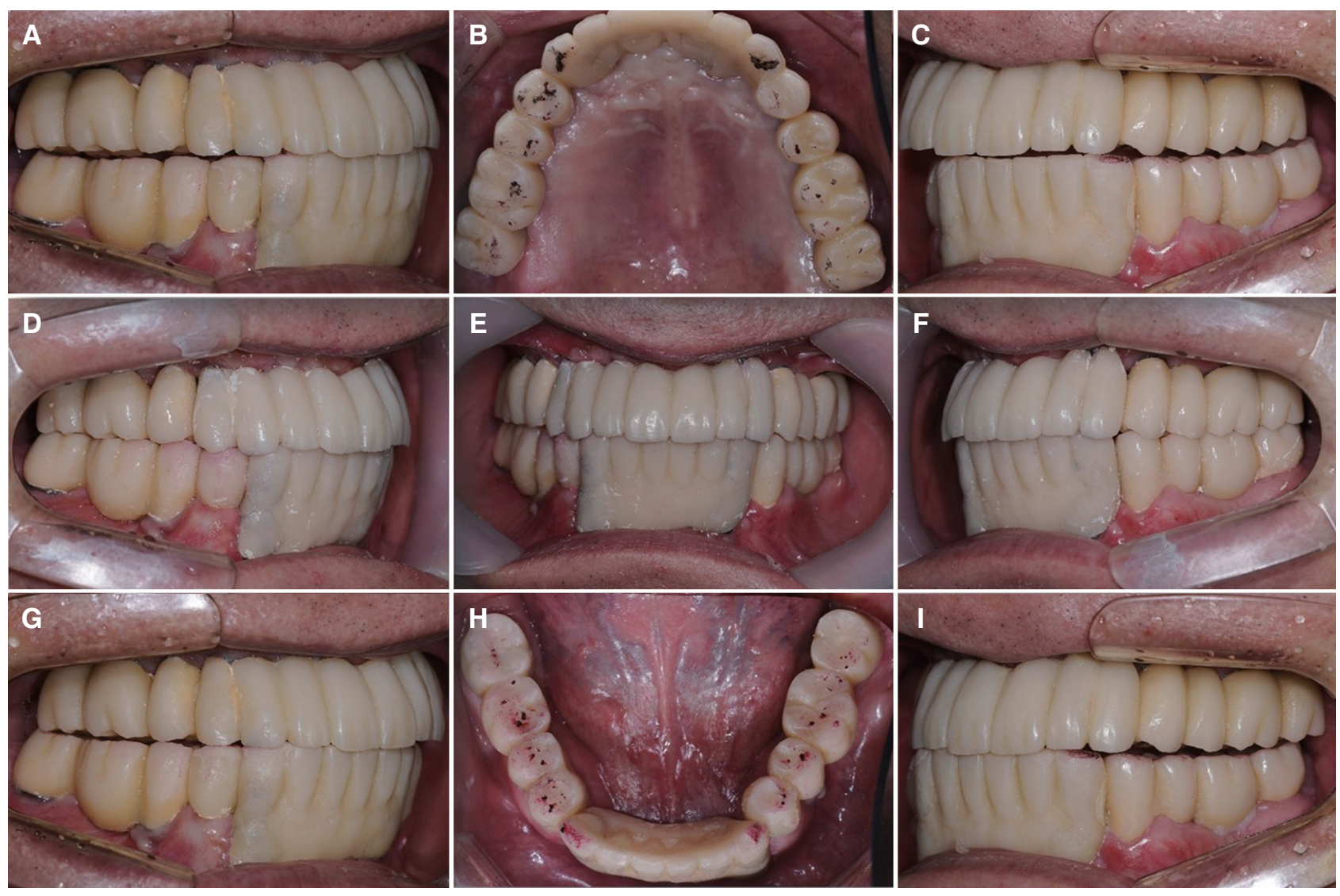

Fig. 5. Provisional restoration. (A) Balancing side during left lateral excursion, (B) Maxillary occlusal view, (C) Working side during left lateral excursion, (D) Right buccal view during centric occlusion, (E) Frontal view during centric occlusion, (F) Left buccal view during centric occlusion, (G) Working side during right lateral excursion, (H) Mandibular occlusal view, (I) Balancing side during right lateral excursion.

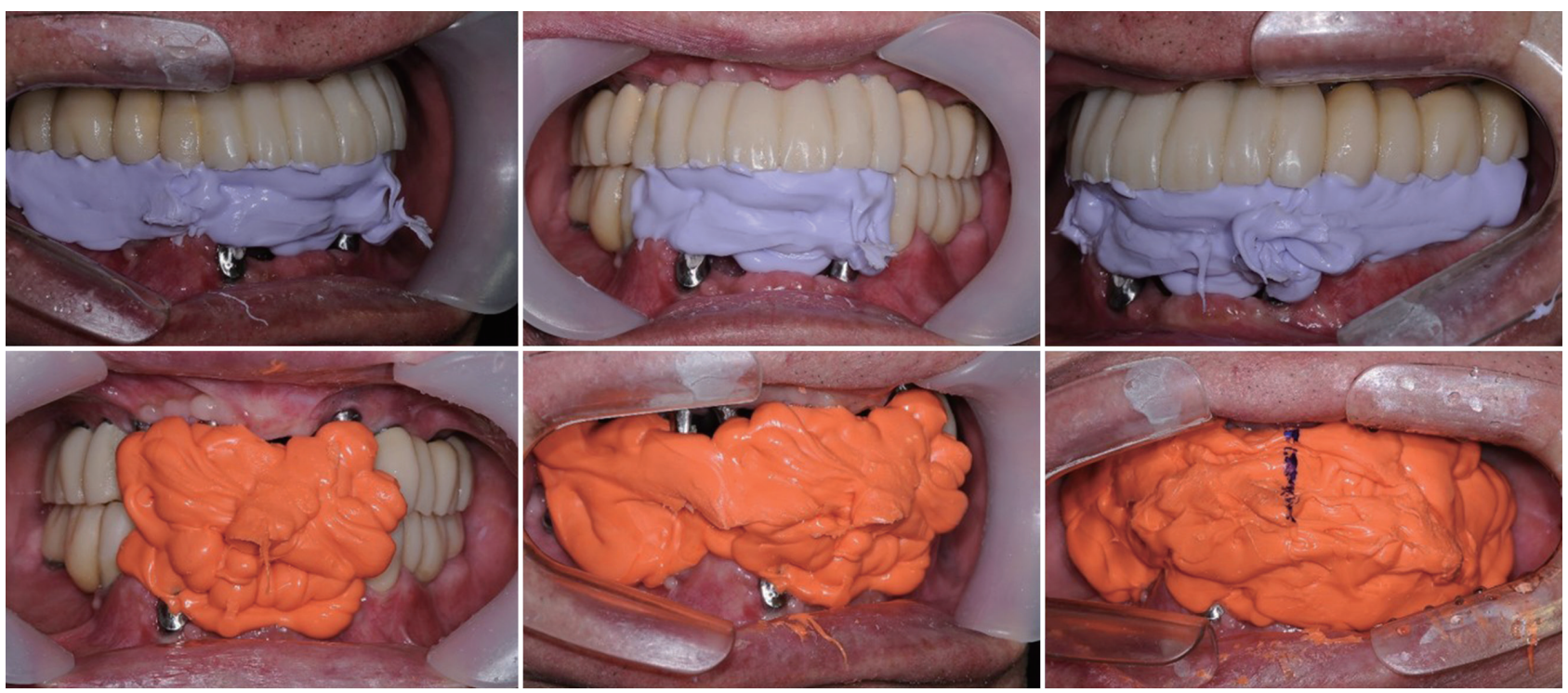

Fig. 6. Intermaxillary relation registration for cross mounting. 

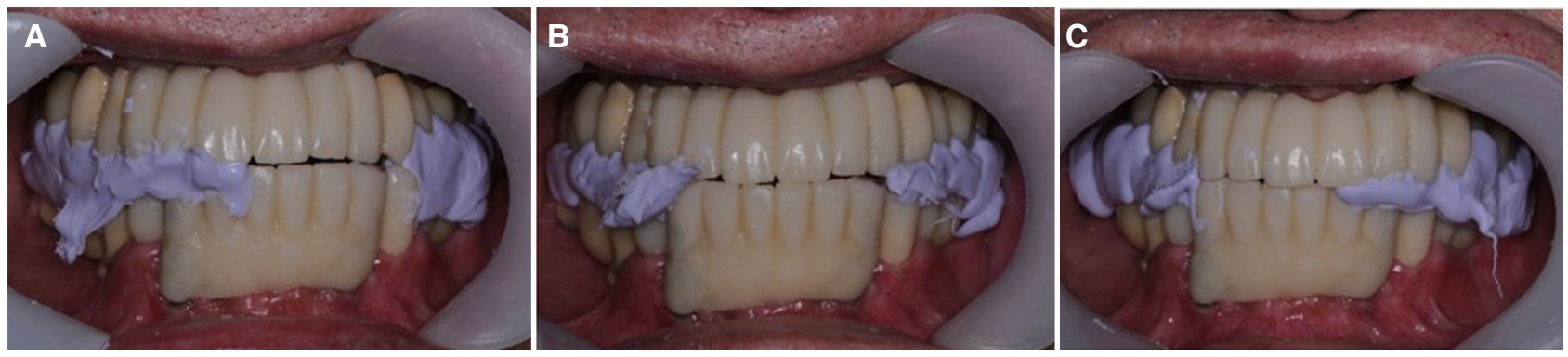

Fig. 7. Check bite registration. (A) Left excursion, (B) Anterior guidance, (C) Right excursion.
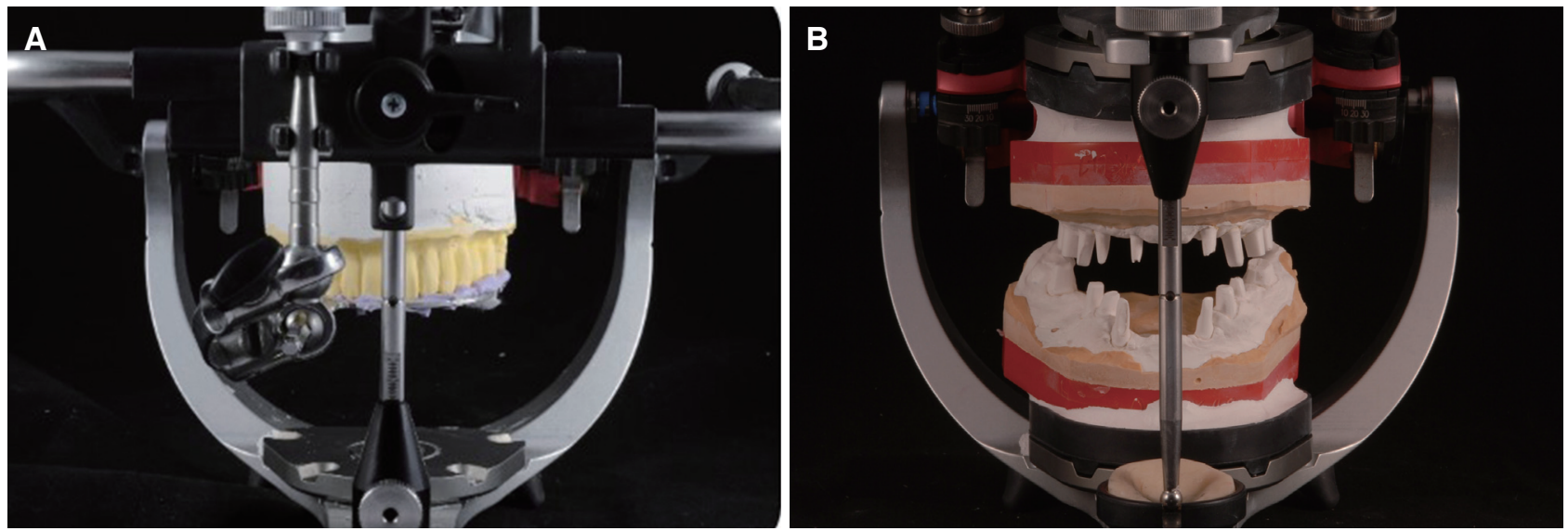

Fig. 8. Mounting on a semi-adjustable dental articulator. (A) Facebow transfer, (B) Cross mounting on a articulator.

방유도로 최종 보철물을 위한 왁스업을 시행했다. $\mathrm{CAD} / \mathrm{CAM}$ 을 이용해 단일 구조 지르코니아(Zirmon, Kuwotech)로 최종보철물을 제작했다(Fig. 9). 골소실이 심한 하악 전치부는 심미성을 위해 잇몸 부위는 gingiva porcelain으로 제작하고 구강위생 관리를 위해 치간 부 위 적절한 공간을 부여했다. 중심교합위시 균등한 교합 접촉이 되고, 전방운동시 모든 후방치아가 이개되고, 측 방운동시 견치 유도 교합이 됨을 확인했다. 최종보철물 장착 후 CT로 확인한 결과 정상적 관절강을 보이고 과 두가 관절와 내에 적절한 위치에 있었다(Fig. 10).

ARCUS digma II에서의 EPA test를 통하여 최대 교두 감합위와 중심위에서의 과두 위치를 비교한 결과 차이 가 거의 없었으며 재연성이 있었다(Fig. 11). 최종 보철 물 장착 후 파노라마 사진으로 확인했다(Fig. 12). 최종 수복물 장착 후 상순 지지가 회복되었으며, 오목했던 측 모가 개선된 것을 확인할 수 있었다(Fig. 13).

\section{고찰}

본 증례에서는 심한 치주질환 환자에서 치주적으로 예후가 좋지 않은 치아를 발치하고 소수치를 잔존시켜 상실부위는 임플란트로 전악 수복하여 적절한 기능과 심미를 얻을 수 있었다. 자연치 치근의 길이는 $20 \mathrm{~mm}$ 정도이고 가장 많이 사용되는 임플란트의 길이는 10 $\mathrm{mm}$ 이다. 스웨덴에서 발표한 연구에 의하면 20세 이후 자연치의 치간골 소실이 연간 $0.1 \mathrm{~mm}$ 라고 했다. ${ }^{11,12}$ 반 면 임플란트의 경우 첫해 $1 \mathrm{~mm}$ 골소실 이후 년 $0.1-0.2$ $\mathrm{mm}$ 정도 골소실을 보인다고 한다 ${ }^{13}$. 심한 치주질환일지 라도 치주치료로 성공적으로 치료할 수 있고, 더 이상의 골소실도 막을수 있다고 한다. ${ }^{13}$ 반면 임플란트 주위염 치료에 대한 장기적 예후에 대해 확실히 알려진 것이 없 다. 치주 질환의 악화를 막을 수 있고 성공적인 치주치 료가 가능하다면 상당한 치조골 소실을 보이는 치아라 


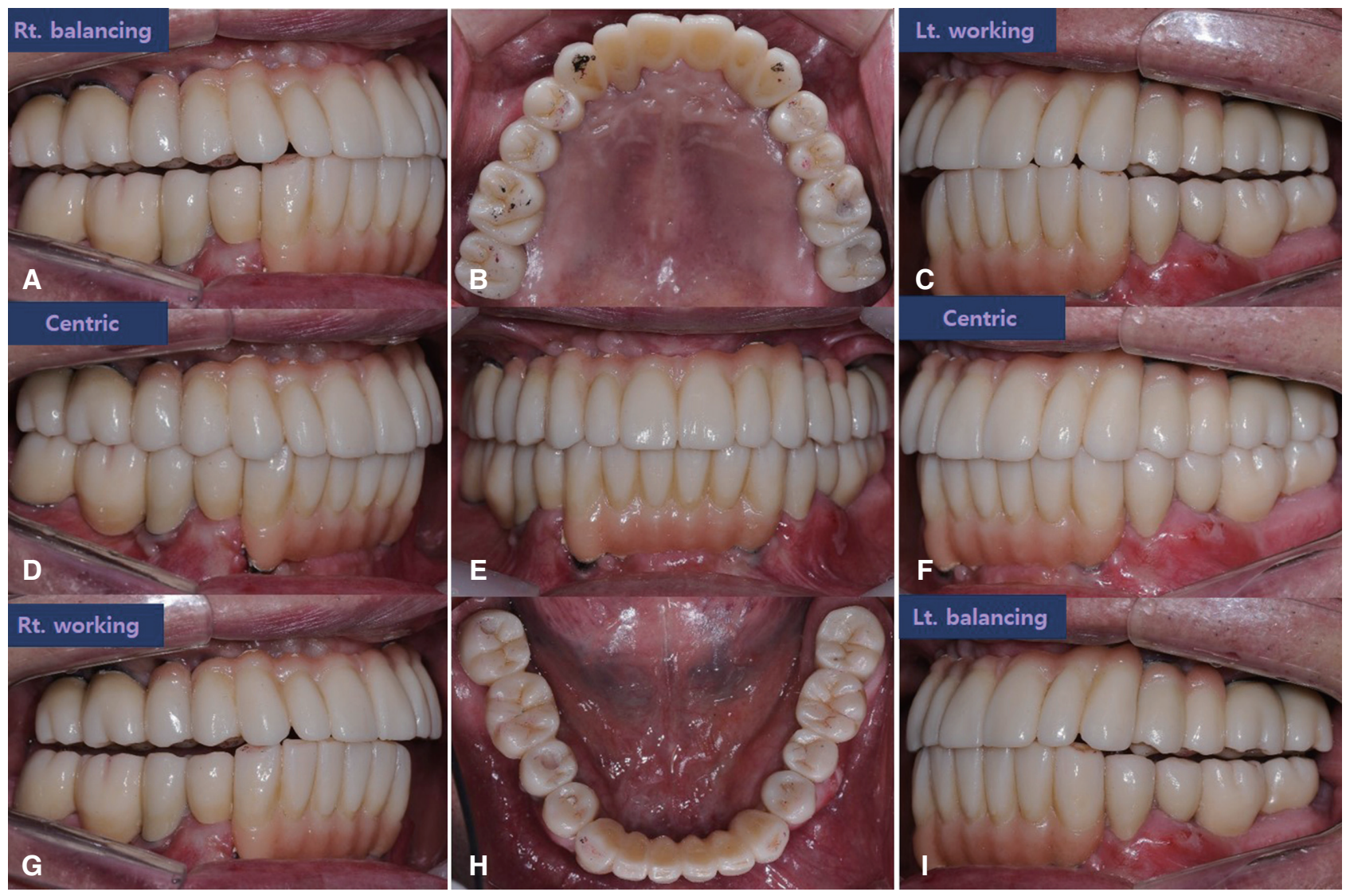

Fig. 9. Definitive restoration. (A) Balancing side during left lateral excursion, (B) Maxillary occlusal view, (C) Working side during left lateral excursion, (D) Right buccal view during centric occlusion, (E) Frontal view during centric occlusion, (F) Left buccal view during centric occlusion, (G) Working side during right lateral excursion, $(H)$ Mandibular occlusal view, (I) Balancing side during right lateral excursion.
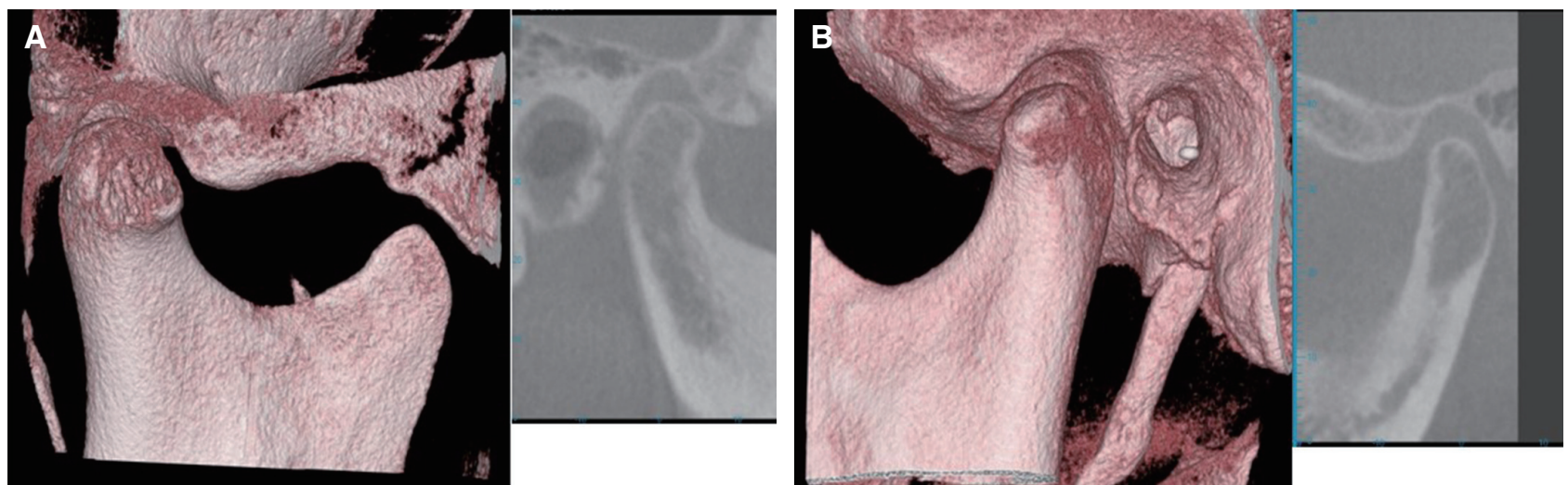

Fig. 10. CT for condylar joint space. (A) Right condyle, (B) Left condyle. 

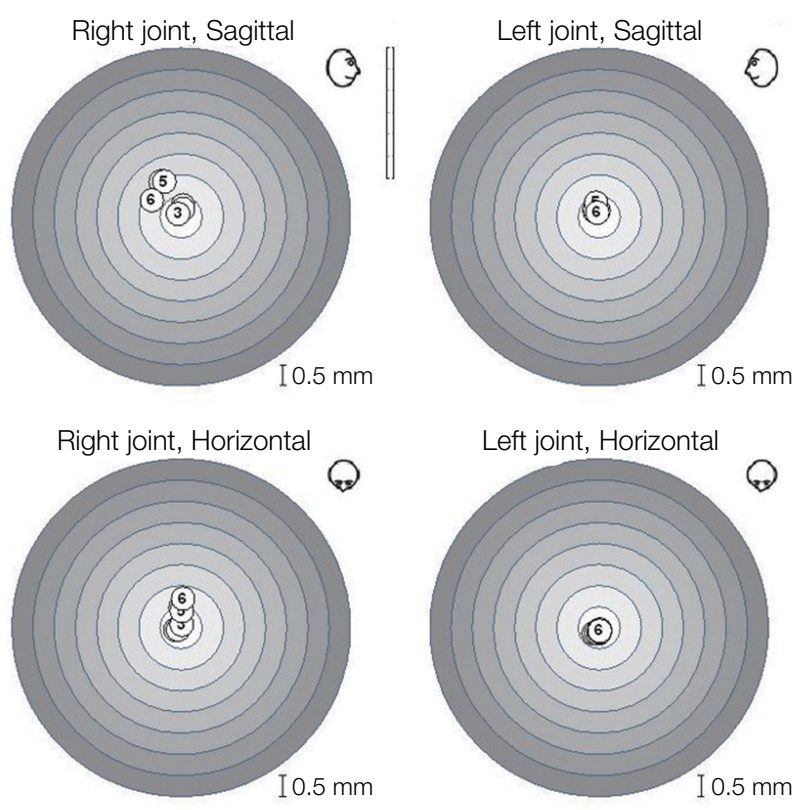

Fig. 11. EPA test by ARCUS digma II. MICP: 1,2 , 3; CR (manipulation): 4, 5, 6 .

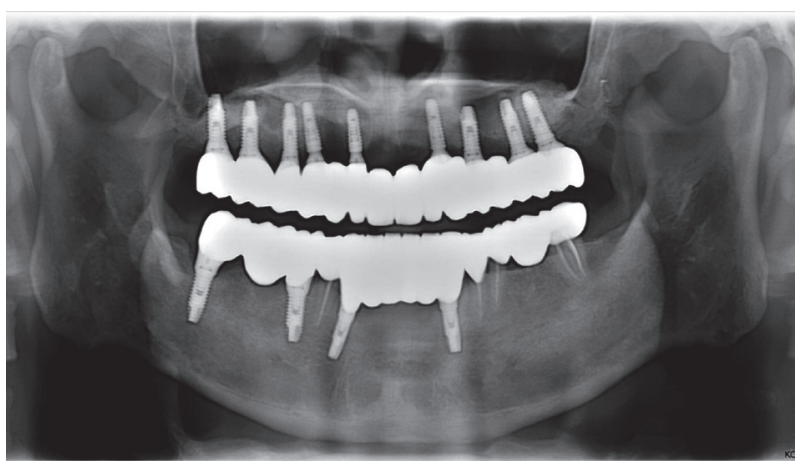

Fig. 12. Postoperative panoramic radiograph.
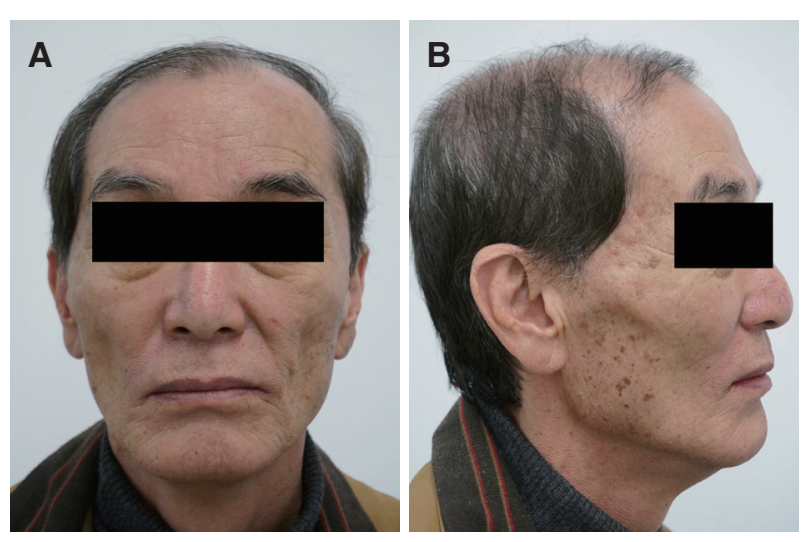

Fig. 13. Postoperative extraoral photos. (A) Frontal view, (B) Side view.
도 발치 후 임플란트로 치료할 이유가 없다. 치조골 소 실을 보이는 치아는 스플린팅하지 않을 경우 동요도를 보이겠지만, 적절한 치주치료 시행시 long span 고정성 보철물의 지대치로 성공적인 사용이 가능하다. 물론 잔 존 주위골 정도를 봐야 하지만 대략 $25-30 \%$ 정도 잔존 치주조직이 있으면 충분하다. ${ }^{14,15}$ Long span 임플란트 고정성 보철물에서 골소실이 있으나 건강한 치주조직일 경우 예후는 불확실하다. 따라서 자연치 발치 후 임플란 트 치료를 생각하기 이전 자연치에 대해서 다시 한번 생 각해 봐야 할 것이다. 만성치주염에 이환된 소수 잔존 치아의 치주치료 후 임플란트를 식립하여 전악수복시 자연치의 존재로 인해 proprioceptive response를 보존 할 수 있어 정상적인 상, 하 악간관계와 이상적인 교합 평면 결정시 도움이 되었을 뿐만 아니라 저작이 용이해 져서 보철물에 대한 환자의 적응이 더욱 쉬웠다. 그러나 이러한 잔존 치아의 치료결과에 대해서는 장기간의 예 후 관찰이 필요하다. 만일 추가발치가 이루어질 경우를 대비하여 환자에게 향후 임플란트의 추가 식립이 필요 하다는 것을 미리 알려주는 것이 필요하리라 사료된다.

\section{Orcid}

Eun-Jung Shin http://orcid.org/0000-0003-3632-2995

Mong-Sook Vang http://orcid.org/0000-0001-6743-5330

Hong-So Yang http://orcid.org/0000-0002-9138-4817

Sang-Won Park http://orcid.org/0000-0002-9376-9104

Hyun-Pil Lim http://orcid.org/0000-0001-5586-1404

Kwi-Dug Yun http://orcid.org/0000-0002-2965-3967

\section{References}

1. Lundgren D, Nyman S, Heijl L, Carlsson GE. Functional analysis of fixed bridges on abutment teeth with reduced periodontal support. J Oral Rehabil 1975;2:105-16.

2. Nyman S, Lindhe J. A longitudinal study of combined periodontal and prosthetic treatment of patients with advanced periodontal disease. J Periodontol 1979;50:163-9.

3. Mengel R, Behle M, Flores-de-Jacoby L. Osseointegrated implants in subjects treated for generalized aggressive periodontitis: 10 -year results of a prospective, long-term cohort study. J Periodontol 
2007;78:2229-37.

4. Hoffmann O, Beaumont C, Zafiropoulos GG. Combined periodontal and implant treatment of a case of aggressive periodontitis. J Oral Implantol 2007;33:288-92.

5. Ekelund JA, Lindquist LW, Carlssson GE, Jemt T. Implant treatment in the edentulous mandible: a prospective study on Brånemark system implants over more than 20 years. Int J Prosthodont 2003; 16:602-8.

6. Attard NJ, Zarb GA. Long-term treatment outcomes in edentulous patients with implant-fixed prostheses: the Toronto study. Int J Prosthodont 2004;17:417-24.

7. Berglundh T, Persson L, Klinge B. A systematic review of the incidence of biological and technical complications in implant dentistry reported in prospective longitudinal studies of at least 5 years. J Clin Periodontol 2002;29 Suppl 3):197-212.

8. Fransson C, Lekholm U, Jemt T, Berglundh T. Prevalence of subjects with progressive bone loss at implants. Clin Oral Implants Res 2005;16:440-6.

9. Roos-Jansåker AM, Lindahl C, Renvert H, Renvert S. Nine- to fourteen-year follow-up of implant treatment. Part II: presence of peri-implant lesions. J Clin Periodontol 2006;33:290-5.
10. Schou S. Implant treatment in periodontitis-susceptible patients: a systematic review. J Oral Rehabil 2008;35 Suppl 1:9-22.

11. Hugoson A, Laurell L. A prospective longitudinal study on periodontal bone height changes in a Swedish population. J Clin Periodontol 2000;27: 665-74

11. Jansson L, Lavstedt S, Zimmerman M. Marginal bone loss and tooth loss in a sample from the County of Stockholm - a longitudinal study over 20 years. Swed Dent J 2002;26:21-9.

12. Adell R, Eriksson B, Lekholm U, Brånemark PI, Jemt T. Long-term follow-up study of osseointegrated implants in the treatment of totally edentulous jaws. Int J Oral Maxillofac Implants 1990;5: 347-59.

13. Laurell L, Lundgren D, Falk H, Hugoson A. Longterm prognosis of extensive polyunit cantilevered fixed partial dentures. J Prosthet Dent 1991;66: 545-52.

14. Nyman S, Ericsson I. The capacity of reduced periodontal tissues to support fixed bridgework. J Clin Periodontol 1982;9:409-14. 


\section{만성 치주염 환자에서 소수 잔존치와 임플란트를 이용한 전악 수복: 증례 보고}

\section{신은정 ${ }^{1}$, 방몽숙 ${ }^{1}$, 양홍서 ${ }^{1 *}$, 박상원 ${ }^{1,2}$, 임현필 ${ }^{1}$, 윤귀덕 ${ }^{1}$}

${ }^{1}$ 전남대학교 치의학전문대학원 보철학교실

${ }^{2}$ 전남대학교 미래형생체부품소재 RIS 사업단

만성 치주염 환자 치료시 잔존치 발치 여부를 결정할 때 신중을 기해야 한다. 고정성 또는 가철성 국소의치 치료시 치 주조건이 불량한 치아를 지대치로 사용하면 과부하로 조기실패가 우려되어 발치를 고려하지만, 임플란트 고정성 보철 물의 경우 잔존치로 전달되는 기능하중을 감소시킬 수 있기 때문에 잔존치를 유지시키는 경우가 많다. 잔존치를 이용 한 전악수복시 proprioceptive response를 보존할 수 있어 악간관계와 교합평면 결정시 도움이 될 뿐 아니라 환자의 보 철물에 대한 적응이 쉽다. 본 증례의 환자는 치주질환에 의해 다수치 상실 및 대합치의 정출을 보였다. 동요도가 심해 예후가 좋지 않은 치아를 발거하고 소수 잔존치와 임플란트로 전악수복하여 적절한 기능적, 심미적 결과를 얻었다.

(구강회복응용과학지 2015;31 (3):253-61)

주요어: 만성 치주염; 소수 잔존치; 임플란트; 전악수복 